\title{
The Impact of Corporate Governance on Financial Reporting Quality: Evidence from Pakistan
}

\author{
Sultan Mehmood ${ }^{1} \quad$ Saira Nazir $^{1} \quad$ Waseem Qadir $^{2 *}$ \\ 1. Riphah International University, Islamabad Pakistan \\ 2. Comsats University, Islamabad Pakistan
}

\begin{abstract}
This research aims to investigate whether corporate governance (CG) mechanisms and Financial Reporting Quality (FRQ) are related with each other in the context of Pakistan. For this purpose panel data is used and a sample of 200 firms is extracted for the period 2003 to 2017. In this study system GMM and STATA software is used for estimation of parameters. The findings suggest that board independence enhances FRQ by $0.0011 \%$ in large sample, $0.0018 \%$ in medium sample and $0.0033 \%$ in small sample. In addition, audit committee independence raises FRQ in all three samples. Specifically, a rise of $1 \%$ in audit committee independence increases FRQ by $0.0088 \%$ in large sample, $0.0083 \%$ in medium sample and $0.0087 \%$ in small sample. Institutional ownership improved the FRQ of Pakistani firms. More specifically, the result indicates that a $1 \%$ rise in institutional ownership bring $0.022 \%$ increase in large sample, $0.029 \%$ in medium sample and $0.018 \%$ in small sample. The results show that a rise of $1 \%$ in gender diversity brings about $42 \%$ increase in large sample, $15 \%$ in medium sample and $7 \%$ increase in small sample. The result indicates that a $1 \%$ rise in shareholder activism is associated with an increase of $6 \%$ (large sample), $28 \%$ (medium sample) and 22\% (small sample) respectively. Concentrate ownership insignificantly affect FRQ in case of large and small sample but on other hand in medium size firm's the relationship is significant and positive with FRQ.
\end{abstract}

Keywords: Financial Reporting Quality, Corporate Governance, Pakistan Stock Exchange.

DOI: $10.7176 /$ RJFA/11-17-17

Publication date:October $31^{\text {st }} 2020$

\section{Preamble}

Governance and Transparency are the two key challenges faced by developing countries. Most academics view these as the key differentiators between developed and developing countries. In the mid-1980s, CG turned into a global issue, in both scholastic and governmental discussion. Some high profile and much publicized corporate scandals in the recent past have put large corporations under immense pressure to improve the quality of information that they report to their stakeholders. One of the important purposes of the financial reporting is decision usefulness (Zeff, 2013). The decision usefulness actually means that relevant and reliable information is available to financial reporting users. The shareholder through financial reporting makes decision regarding assessing the future cash flows of the project in which companies are interested to invest.

The main dilemma is that there are varying levels of institutional controls on what corporations report across different countries. It is obvious that financial transparency minimizes asymmetric information as a result debt capital and equity cost declines (Francis et al., 2004), liquidity of the market raises (Diamond \& Verrecchia, 1991) and corporate performance boosts. According to Mulili (2014) every country has adopted unique corporate governance procedures which are purely based on their set of ownership structure, legal and financial system of the country, culture and economic circumstances, and stability. In the recent years corporate governance issues attracted a considerable amount of regulatory attention which suggests that the strong corporate governance practices would curtail the opportunistic behavior of the managers thus improving the quality of the financial reporting which in turn will help to maintain and enhance the investor's confidence and will reduce the chances of the firm going into financial distress (Flora, 2006).

The stakeholders, users of the financial statement and some regulatory bodies have expressed their concerns about failure of the firms and the weakness of corporate governance structure (Ellouni \& Gueyle, 2001). During the late 1980 and 1990, the corporate bankruptcies reached epidemic proportion (Bortiz, 1991; Altma, 1993; Gales $\&$ Kesner, 1994) and the main reason for these bankruptcies has been linked to the weak corporate governance structure. The prominent corporate scandals that emerge in the developed economies of the world have raised the worry about CG, and particularly about disclosure and transparency. For these scandals the absence of good CG in such prominent organizations was the main reason (Reddy et al., 2008; Reddy et al., 2011). As a result, in last few years significant effort has been made world-wide in order to issue CG standards and measures to guarantee that great practices are set up with the goal that organizations can be shielded from financial distress (Solomon, 2007; Magrus, 2012).

Companies are mostly concerned with raising capital, maintaining liquidity and profitability. In developing countries, CG significance has been raised due to the high demand of capital requirement (McGee, 2009). The CG is viewed as significant for the survival and benefit of the organizations for the very reason; it manages the internal 
management practices as well as has principle worry for the company's association with outside stakeholders that essentially include regulatory bodies, suppliers and shareholders. CG aims at reducing interest conflicts among various stakeholders (Denis \& McConnell, 2003). In the absence of CG practices, the value of the firm declines. Bruce (2009) considers CG practices as a meticulous way in which only the capital provider gets the fitting rewards in a lawful and good way. The central purpose of this examination is to explore whether CG systems decidedly influence FRQ in developing nations, such as, Pakistan.

\title{
1.1 Statement of Problem
}

The current financial deception happened internationally has increased criticism on Financial Reporting Quality (FRQ). The financial disclosure failure has created the need to improve FRQ (Beekes \& Brown, 2006; Brown \& Caylor, 2006; Karamaou \& Vafeas, 2005; Firth et al., 2007; Hussan, 2011). The connection between CG and FRQ has been unequivocally investigated in developed nations. They emphasis on specific governance factors like board concerted shareholding, independence, director shareholding and audit performance. In any case, Pakistan's market is growing day by day so it is important to research this association. This examination is a push to fill the gap in the context of Pakistan.

\author{
1.2 Research Questions \\ i. What is the impact of institutional ownership on FRQ? \\ ii. Is there any link between concentrated ownership and FRQ? \\ iii. Does shareholder activism influence FRQ? \\ iv. Does board meeting frequency influence FRQ? \\ v. Does gender diversity influence FRQ? \\ vi. Does board independence influence FRQ? \\ vii. Does audit independence influence FRQ?

\subsection{Research Objectives} \\ i. $\quad$ To study the influence of Institutional ownership on FRQ; \\ ii. $\quad$ To explore the link between concentrated ownership and FRQ; \\ iii. To explore the link between shareholder activism and FRQ; \\ iv. $\quad$ To study the effect of board meeting on FRQ; \\ v. To investigate the effect of gender diversity on FRQ; \\ vi. $\quad$ To explore the influence of board independence on FRQ; \\ vii. To investigate the impact of audit independence on FRQ.
}

\section{Literature Review}

According to Biddle, Hilary and Verdi (2009) information about cash flows and firm operations towards investors is conveyed through FRQ. Tang, Chen and Zhijun (2008) argue that financial reporting quality provides information about performance and financial position of organization. Hence, the objective of financial reporting quality is to provide useful information for all users while making appropriate decisions about the timing, amount, investment credit, redemption and loans etc.

This study follows agency theory which according to Asegdew (2016) is a contract between shareholders and management. The management work on behalf of the shareholders as they do not have sufficient time to monitor manager's activities. However, management mostly involved in achieving their personal goals because the principals not involve in day to day activities to have a check on management. Corporate governance protects the minority investor's interests by mitigating the conflict of interest between agent and principle. Due to ownership and control separation the agency problem arises. As compare to shareholders, managers have superior information due to which shareholders have to monitor the activities of managers for which they face agency cost.

The manger most of the time at the expense of capital providers pursue their own self-interest (Jensen, 1986). The finance providers require that managers should disclose all accounting information to them, so that they can monitor their interest and wealth (Watts \& Zimmerman, 1986). Managers can overstate financial statement through their accounting estimates and standards as they are the one who provide such information to investors. Corporate governance therefore is the mechanism which minimizes this problem between finance providers and managers and increases the efficiency of the firm (Gomphers et al., 2003). CG and FRQ association in the view of Arthur Levitt (financial securities chairman) is:

"A functioning and successful top managerial staff, dependable budgetary administration, wary and free auditors, and mindful regulatory authorities all have duties to defend the individuals who put resources into public enterprises. Successful CG of the financial reporting procedure is a significant device for empowering firms and their auditors to satisfy those obligations (Levitt, 1998)."

Hence, one of the most significant elements of CG is to guarantee the financial reporting quality (Cohen et 
al., 2004). Lopez-de-Silances (2002), contend that organizations with excellent CG demonstrates more noteworthy FRQ in term of lower level of earning management, higher stock return and greater earnings persistence. Rezaee (2004), suggest that well balance CG mechanism improves the quality and integrity of financial reporting. Cohen et al. (2004) considers CG as an important tool for the corporations to ensure the quality of financial reporting, as high accounting and financial reporting quality reduces asymmetric information, increases transparency and provides better controlling devices (Watts \& Zimmerman, 1986). According to Kin et al. (2014) internal CG attributes plays an important role in overseeing the process of financial reporting and monitoring of the management. Internal governance mechanism curbs inappropriate earning management and limits manager's abilities to manipulate and distort financial statements.

Various investigations in developed nations have announced positive connection between board independence and FRQ (Peasnell et al., 2000; Klein, 2002). According to Peasnell et al. (2000), as independent directors don't perform an immediate part in the administration of the organization, however they are crucial for producing financial reports of high quality and hence their presence bring effectiveness to the board. Klein (2002) findings indicate that FRQ and the percentage of outside directors are negatively correlated.

Asedgew (2016) employ simple random sampling method to investigate FRQ and auditors type of 14 large manufacturing firms over five year period from 2005 to 2010. The results of panel regression analysis showed that financial reporting quality had statistically significant relationship with type of auditors and shares dispersion.

For a sample of Nigerian firms, Patrick et al. (2015), explore the link between board composition and performance of the firm as well as managers opportunistic behaviour. They employ purposive sampling methodology and secondary data was collected for 2011 to 2014. The research results clarify that manager opportunistic behaviour is significantly influenced by presence of audit committee, independence of the board and size of the board.

Kent and Stewart (2008) explore whether disclosure level and corporate governance are significantly related and used Australian listed companies as a sample. The results showed that disclosure were significantly associated to some features of governance such as the occurrence of board size and choice of auditor. Ayadi and Boujelbene (2014) investigated the link between ownership structure and earnings quality for the period 2003 to 2011 in the context of France. Employing panel data method the result of linear regression shows that institutional ownership and earnings informativeness have positive correlation.

Chtourou et al. (2001) examines whether board as well as audit committee characteristics affect earnings management. Their result indicates that earning management decreases with increase of outside directors in the audit committee. For a period of 2005 to 2007, Murhadi (2009) explore the association between audit committee and earnings management. Their sample comprise of firms listed on Indonesian Stock Exchange. However, they find insignificant link between audit committee and earnings management as the audit committee is under the influence of CEO and other senior management of the board.

For a sample of Portuguese Stock Exchange listed firms, Gois (2011) explore the influence of CG on FRQ for the period between 1996 and 2001. Portuguese stock exchange issued the relevant data of companies in the form of annual reports, and papers. This study used annual reports for collecting the necessary components. The study used multivariate regression model. The results shows that CG and FRQ association were not authenticated and also CG does not produce any effect on the FRQ of Portuguese listed non-financial companies.

Razali and Arshad (2014) explore the association between CG disclosure and fraudulent financial reporting in Malaysia. Their study sample comprise of 227 firms for the period 2010-2011. The research indicates that audit committee independence have negative significance influence on the likelihood of fraudulent financial reporting. Audit committee independence decreases the chances of likelihood of fraudulent financial reporting and increases financial statements quality.

Abdullah and Latif (2015) study the impact of audit independence on discretionary accruals from 2003-2012. Their study sample comprises of 120 firms listed on KSE. The result indicates that there is inverse association between audit independence and discretionary accruals. They further finds that an independent audit committee is an effective CG mechanism which ensures that financial reports remain neutral and transparent.

For a sample of 34 firms, Alves (2012) try to find out whether ownership of management and FRQ has any association. They find that earning manipulation and management ownership are negatively correlated. Specifically, he finds that management ownership inhibits earnings management. The managers who own a significant amount of share in equity of the firm have fewer incentives to manipulate reported accounting information. For the period 2004, Hashim and Devi (2008) examined the link between managerial ownership and earnings quality. They used a sample of 280 Malaysian firms. Their research shows that there is a significant positive association between managerial ownership and earnings quality. The research further reveled that managerial ownership plays a significant role in constraining quality of reported earnings.

Velury and Jekins (2006) studied the connection between institutional ownership and quality of earnings. Their findings indicate that institutional ownership positively affects quality of earnings. Furthermore, in a similar study Abdullah (1999) explore the impact of institutional ownership on quality of earnings in the context of 
Malaysian firms. The findings indicate that there is negative association between the two variables, suggesting that Malaysian investors prefer short term return over the long term profitability of the firm supporting the myopic investor hypothesis. Balsam et al. (2000) argue that institutional investors are more professional and have long term goals; they also are more capable in handling accounting data due to their access to relevant and timely information.

For a sample of Thai firms, Pongsaporamat (2016) examine the impact of ownership structure on FRQ proxied by accounting restatement. The results indicate that institutional ownership and accounting restatement are positively linked, showing that such firms have more tendencies to restate their financial statement; therefore they have low quality of financial reporting.

$\mathrm{Zia}$ (2017) used panel regression technique to find the effect of the CG mechanisms on FRQ of financial sector in Pakistan. The data were composed of 26 financial firms registered in Pakistan for the period of 2005 to 2014. The results of panel regression analysis showed that board liberation had progressive and insignificant relation with financial reporting quality. However, CEO duality, board size, leverage and firm size does not effect FRQ.

For the period 2007 to 2011, Shaer and Salama (2017) investigate the environmental accounting disclosure and their quality in UK, with specific effort on the part of audit committee and FRQ. Their study sample consists of 350 FTSE UK firms. The result showed that the firm with advanced feature audit committee marks higher quality disclosure. Large sample had superior capacity of disclosure with block stockholders although audit committee quality does not improve discloser capacity. Findings were built on indication from single country and involve additional universal relative research.

Bajra and Cadez (2018) investigate the influence of audit on FRQ. The period under examination is from 2004 to 2013 . The period covers the era earlier and later the procedure of the $8^{\text {th }}$ company law directive, thus permitting for an examination of the directive's Influence on FRQ. The study find that audit committee observing efficiency and audit committee capabilities connected positively with financial reporting quality, on the other hand influence of the presence of an audit committee was negative.

Bradbury and Cahan (2009) studied the link between CG, external audit fees and audit quality. The study used 87 New Zealand companies as a sample for the period 2001. The results showed that quality of an audit committee and FRQ are significantly related. Likewise the quality of audit committee had slight influence on the level of fees funded to external auditors. For a sample of Tunisian firms, Klai and Omri (2011) studied the link between board of director's characteristics and FRQ during the period 1997 to 2007 . They found that governance and FRQ are significantly related with each other; in addition they found that there is negative link between black holders, families' ownership and FRQ.

\subsection{Research Hypotheses}

$\mathrm{H}_{1}$ : Board independence significantly affects FRQ;

$\mathrm{H}_{2}$ : Concentrated ownership significantly affects FRQ;

$\mathrm{H}_{3}$ : Shareholder activism significantly affects FRQ;

$\mathrm{H}_{4}$ : Board meeting significantly affects FRQ;

$\mathrm{H}_{5}$ : Gender diversity significantly affects FRQ;

$\mathrm{H}_{6}$ : Audit independence significantly affects FRQ;

$\mathrm{H}_{7}$ : Institutional ownership significantly affects FRQ.

\section{Research Methodology}

The previous chapter shows literature and hypothesis of the study whereas the current chapter provides research design of the study to test hypothesis. This chapter clarifies selection of sample, data collection and sources, and the period of study. This chapter also provides the model of the study.

\subsection{Research Design and Data Sources}

Research design is the basic plan for a piece of empirical research. Research design associate research questions with data and the tools and procedures to be used for collecting and analyzing data. Panel data is used in the current study. STATA software is used to analyses the data as it is suitable for panel data regression. Secondary data is used in this study. Secondary data is acquired from company annual reports, Pakistan Stock Exchange (PSX) website and State Bank of Pakistan website.

\subsection{Population and Sample}

Scholars usually study a subsection of population which is known as sample. All PSX listed non-financial firms are used as study population. However, a sample of 200 firms is extracted over the period 2003-2017. The sample of 200 firms is taken because these firms have completed data available for all years.

Table 1. Summary of Variables 


\begin{tabular}{|l|l|l|}
\hline Variables & Label & Measurement \\
\hline Dependent Variable & & \\
\hline $\begin{array}{l}\text { Financial Reporting } \\
\text { Quality }\end{array}$ & FRQ & Accrual Quality \\
\hline Independent Variables & & \\
\hline Concenter Ownership & COS & Share held by top 5 shareholders \\
\hline Shareholder Activism & SHA & $\begin{array}{l}\text { Number of board meeting attend by directors/total number of board } \\
\text { meeting }\end{array}$ \\
\hline Board independence & BORD & Number of independent directors on the board/total directs \\
\hline Institutional ownership & INSTOWN & Number of independent directors /total no of directs \\
\hline Gender Diversity & GD & Female representation on the board \\
\hline Audit Independence & ACI & Percentage of independent directors on audit committee \\
\hline Board Meeting Frequency & BMF & Number of board meetings held in a year \\
\hline Control Variables & PROF & Profit after tax /total assets \\
\hline Profitability & LEV & Debt/equity \\
\hline Leverage & SIZE & Total assets/sales \\
\hline Firm size & GR & Change in total assets \\
\hline Growth &
\end{tabular}

\subsection{Model Specification}

In this study the system GMM is used to explore the relation between governance and FRQ. The software used for estimation of parameters is STATA 12. Gujarati (2003) suggests four critical assumptions (homoscedasticity, normality, independence of error terms, linearity) that must be met before utilizing parametric tests hence; these tests were performed before running GMM. Furthermore, for tackling endogeneity the study used GMM regression because endogeneity is a problem which makes the parameters biased and inconsistent (Roberts \& Whited, 2011). The dependent variable is used as lag variable on the right hand side so the model becomes dynamic whereas the independent variables lag values are used as instruments. The following GMM regression model is used to study the relation between $C G$ and FRQ:

FRQi, $t=\alpha+\beta 1$ (FRQ)i,t- $1+\beta 2(\mathrm{COS}) \mathrm{i}, \mathrm{t}+\beta 3$ (PROF)i,t+ $\beta 4$ (INST)i,t+ $\beta 5$ (SIZE)i,t+ $\beta 6$ (SHA)i, $t+$

$\beta 7(\mathrm{BIND}) \mathrm{i}, \mathrm{t}+\beta 8(\mathrm{BMF}) \mathrm{i}, \mathrm{t}+\beta 9(\mathrm{GD}) \mathrm{i}, \mathrm{t}+\beta 10(\mathrm{GR})+\varepsilon \mathrm{i}, \mathrm{t}$

Where,

$\mathrm{FRQ}_{\mathrm{it}}=$ Financial reporting quality of company $\mathrm{i}$ at time $\mathrm{t}$;

$\beta 0=$ Intercept;

COS it $=$ Concentrated ownership;

$\mathrm{INST}_{\mathrm{it}}=$ Institutional ownership;

$\mathrm{PROF}_{\text {it }}=$ Firms profitability;

$\mathrm{ACI}_{\mathrm{it}}=$ Audit independence;

$\mathrm{SIZE}_{\text {it }}=$ Size of company;

$\mathrm{GR}_{\mathrm{it}}=$ Growth of company;

BMFit = Board meeting frequency;

$\mathrm{SHA}_{\mathrm{it}}=$ Shareholder activism;

$\mathrm{GD}_{\text {it }}=$ Gender diversity;

$\mathrm{BIND}_{\text {it }}=$ Board independence;

$\beta 1-\beta 10=$ Coefficient parameters;

$\epsilon_{\mathrm{it}}=$ Error term.

\section{Empirical Results and Analysis}

\subsection{Introduction}

This study aims to examine the financial reporting quality of the non-financial companies listed at the Pakistan stack exchange. For the investigation of the impact of CG on FRQ this study employ the accounting and nonfinancial data of the related firms. In this section correlation analysis, descriptive statistics and regression analysis of the variables are discussed. The chapter is organized as follows: Section 4.1 presents the introduction; section 4.2 provides the descriptive statistics, section 4.3 is related to correlation analysis and section 4.4 presents GMM regression results.

\subsection{Descriptive Statistics}


Descriptive statistics presents the mean, SD, minimum and maximum values of the independent and depended variables. The descriptive statistics results of small, medium, and large sample are shown in Table 2, 3 and 4 . The descriptive statistics of large sample is shown in Table 2. As shown financial reporting quality of large sample has a mean value of 0.6031 and standard deviation of 0.1387 . However, the mean financial reporting quality of medium and small size firms is 0.5397411 and 0.4847767 respectively.

The explanatory variable profitability of large sample has a mean value of 0.1071 and standard deviation of 0.1055 with a minimum value of -0.3572 , and maximum value of 0.4319 . On the other hand medium size firms have mean profitability of 0.0487428 and small size firms have a mean profitability of -0.0018427 . The concentrate ownership (COS) of large sample has a mean value of 11.6358 with a standard deviation of 21.05809. However, in small size firms; ownership is more concentrated where mean COS is 35.69237 as compare to 24.78096 of medium size firms. Thus, the findings shows that ownership in large sample is dispersed however majority ownership in small sample is held by few shareholders. Furthermore, in large sample institutional ownership is higher where the mean INST is 65.0434. However, small sample have lower institutional ownership with a mean value of 28.79835 .

The mean value of the variable GD of large sample is 0.1765597 as compare to the mean value of medium companies 0.3884983 and small companies 0.5040393 . Thus, in small companies the representation of women on board is higher as opposed to large and medium companies. Small sample are mostly family firms therefore women from the family usually sit on the board. The variable SHA has 0.8019 mean value in large sample as compare to 0.7960 of medium sample and 0.8077 of small sample. The number of meetings held in large sample is higher as contrast with small as well as medium sample. The mean BMF of large sample is 6.066381 followed by medium size firms (5.277778) and small size firms (5.247863).

Large size firms have higher board independence with the mean value of 0.6644017 as opposed to the mean of 0.6360203 in medium sample and 0.6100056 in small sample. Similarly, large size firms have higher audit committee independence with a mean value of 0.8638544 . The mean ACI of medium sample is 0.8113889 and the mean ACI of small sample is 0.7700855 . Furthermore, minority shareholders representation on the board of large size firms is higher with a mean MSH of 0.5310 as compare to the mean MSH of 0.2425214 in medium sample and means MSH of 0.15598 in small sample.

Table 2. Descriptive of Large Size Firms

\begin{tabular}{|l|l|l|l|l|l|}
\hline Variables & Obs & Mean & Std. Dev. & Min & Max \\
\hline FRQ & 467 & 0.6031107 & 0.1387542 & 0.25 & 0.9444 \\
\hline Prof & 467 & 0.1071163 & 0.105519 & -0.3572 & 0.4319 \\
\hline SIZE & 466 & 10.02709 & 1.288501 & 4.484 & 14.0736 \\
\hline COS & 467 & 11.6358 & 21.05809 & 0 & 88.5 \\
\hline GD & 467 & 0.1765597 & 0.2318017 & 0 & 1 \\
\hline SHA & 467 & 0.8019537 & 0.1118273 & 0.4222 & 1 \\
\hline GR & 440 & 0.2900861 & 2.220785 & -0.5005 & 46.3167 \\
\hline INST & 467 & 65.0434 & 28.14941 & 0.77 & 98.5 \\
\hline BMF & 467 & 6.066381 & 3.556697 & 3 & 35 \\
\hline BIND & 467 & 0.6644017 & 0.2422078 & 0 & 1 \\
\hline ACI & 467 & 0.8638544 & 0.2110167 & 0 & 1 \\
\hline
\end{tabular}

Table 3. Descriptive of Medium Size Firms

\begin{tabular}{|l|l|l|l|l|l|}
\hline Variables & Obs & Mean & Std. Dev. & Min & Max \\
\hline FRQ & 936 & 0.5397411 & 0.1144432 & 0.25 & 0.9306 \\
\hline Prof & 936 & 0.0487428 & 0.0933582 & -0.6218 & 0.6552 \\
\hline SIZE & 929 & 8.075545 & 1.092516 & 1.1132 & 11.8646 \\
\hline COS & 936 & 24.78096 & 26.57551 & 0 & 97.47 \\
\hline GD & 936 & 0.3884983 & 0.2872246 & 0 & 1 \\
\hline SHA & 936 & 0.7960824 & 0.1165127 & 0.3673 & 1 \\
\hline GR & 843 & 0.5739757 & 11.13715 & -1.4592 & 323.1718 \\
\hline INST & 936 & 47.69495 & 29.68737 & 0 & 98.84 \\
\hline BMF & 936 & 5.277778 & 2.09909 & 2 & 28 \\
\hline BIND & 936 & 0.6360203 & 0.2048602 & 0 & 1 \\
\hline ACI & 936 & 0.8113889 & 0.2102527 & 0 & 1 \\
\hline
\end{tabular}


Table 4. Descriptive of Small Size Firms

\begin{tabular}{|l|l|l|l|l|l|}
\hline Variables & Obs & Mean & Std. Dev. & Min & Max \\
\hline FRQ & 468 & 0.4847767 & 0.0997617 & 0.2083 & 0.75 \\
\hline Prof & 468 & -0.0018427 & 0.1348121 & -1.2071 & 0.7836 \\
\hline SIZE & 466 & 6.975333 & 1.52426 & 0 & 9.6658 \\
\hline COS & 468 & 35.69237 & 27.52889 & 0 & 93.11 \\
\hline GD & 468 & 0.5040393 & 0.2851939 & 0 & 1 \\
\hline SHA & 468 & 0.80776 & 0.1207868 & 0.3929 & 1 \\
\hline GRS & 419 & 0.2270649 & 0.8182646 & -0.9827 & 9.2331 \\
\hline INST & 468 & 34.19466 & 28.79835 & 0 & 95.22 \\
\hline BMF & 468 & 5.247863 & 2.167132 & 3 & 19 \\
\hline BIND & 468 & 0.6100056 & 0.2153984 & 0 & 1 \\
\hline ACI & 468 & 0.7700855 & 0.2435242 & 0 & 1 \\
\hline
\end{tabular}

4.3 Regression Analysis

The results of GMM are provided in Table 5. In order to test instruments validity the study employed the Hansen test. In Hansen test rejection of null hypothesis is required as it indicates that error term is correlated with null hypothesis. Thus, Ho is rejected in this case as the P-value is $>0.05$ which suggests that the instruments used are valid instruments. Further, to check whether the problem of autocorrelation is present in the data the study uses Arellano-Bond test which indicates that $\mathrm{p}$-value is $<5 \%$. Hence, there is no autocorrelation in the dataset.

The findings suggest that board independence enhances FRQ by $0.0011 \%$ in large sample, 0.0018 in medium sample and 0.0033 in small sample. Thus, independence of the board and FRQ are positively correlated the findings also indicate that the variable board independence brings higher increase in FRQ in small sample. According to Higgs Report (2003) independent directors monitor the activities of the board and management and thus perform a significant role in enhancing financial reporting quality. In a similar vein, Peasnell et al. (2000) argue that the reason why independent directors improve FRQ is because they are not directly involved in company's management. Prior literature in developed nations also shows that independence of the board and FRQ are positively linked (Peasnell et al., 2000; Klein, 2002). Klein (2002) finds that FRQ and the percentage of outside directors are positively correlated. Chtourou et al. (2001) result indicates that earning management decreases with increase of outside directors. Patrick et al. (2015) research finding shows that earning management practices are significantly influenced by independence of the board.

In addition, audit committee independence raises FRQ in all three samples. At the 1\% level these results are highly significant. Specifically, a rise of $1 \%$ in audit committee independence increases FRQ by $0.0088 \%$ in large sample, $0.0083 \%$ in medium sample and 0.0087 in small sample. More often than not managers are involved in earning management so as to cover their astute conduct. The audit committee play an effective role in improving financial statements quality and hence FRQ by monitoring the work of internal auditors. Patrick et al. (2015) shows that earning management practices are significantly influenced by presence of audit committee. Razali and Arshad (2014) indicates that audit committee independence have negative significance influence on the likelihood of fraudulent financial reporting. Audit committee independence decreases the chances of likelihood of fraudulent financial reporting and increases financial statements quality. Abdullah and Latif (2015) indicate that audit committee independence is inversely linked with earnings management practices. They further finds that audit committee independence is an effective CG mechanism and ensures that financial reports remain neutral and transparent.

Hypotheses 7 is about the effect of institutional ownership on FRQ. The positive signs $(\mathrm{p}<0.05)$ on institutional ownership measure provide support for Hypothesis 7, indicating that institutional ownership improved the FRQ of Pakistani firms. More specifically, the result indicates that a $1 \%$ rise in institutional ownership bring $0.022 \%$ increase in large sample, $0.029 \%$ in medium sample and $0.018 \%$ in small sample. According to Daily et al. (2003) the presence of institutional investors protects minority shareholders' interests and performs a significant monitoring role on the board. As compare to individual shareholders institutional investors have greater inside information, as they have large stake in the equity of the firm and generally spend more time monitoring the firm. Most of the time when the firm financial performance declines, institutional investors can pressurize management and even most of the time they withdraw their investment immediately from the poor performing firms (Chi-Keung Man \& Wong, 2013). Velury and Jekins (2006) findings indicate that institutional ownership has direct positive relation with quality of earnings. Balsam et al. (2000) argue that institutional investors are more professional and have long term goals; they also are more capable in handling accounting data due to their access to relevant and timely information.

The variable gender diversity has significant positive relationship with FRQ because P-value is less than 0.05 in small, medium and large sample. The coefficient show that a rise of $1 \%$ in gender diversity brings about $42 \%$ 
increase in large sample, $15 \%$ in medium sample and $7 \%$ increase in small sample. Shareholder activism is other explanatory variable where the coefficient FRQ is significant and positive in all three samples of small, medium and large samples. The result indicates that a $1 \%$ rise in shareholder activism is associated with an increase of $6 \%$ (large sample), 28\% (medium sample) and 22\% (small sample) respectively. Hence, our Finding is in line with Yetmen and Yetman (2004). In terms of board meeting frequency and FRQ we expect positive and significant coefficients for BMF variable. However, the coefficient on BMF is insignificant in all three samples. Titus Rotich (2017) also finds insignificant relation between the two variables in his study.

Concentrate ownership insignificantly affect FRQ in case of large and small sample but on other hand in medium size firm's the relationship is significant and positive with FRQ. A 1\% increases in concentrated ownership is associated with a decrease of 0.001 in FRQ in the case of medium size firms. The variables monitory shareholder representation and board meeting frequency does not affect FRQ. Furthermore, the control variables leverage, growth, firm size, and profitability have positive and significant association with FRQ in all three samples.

Table 5. Regression Results

\begin{tabular}{|l|l|l|l|}
\hline Variables & Large sample & Medium sample & Small sample \\
\hline FRQ (-1) & $0.9286^{* * *}$ & $0.9157^{* * *}$ & $0.9593^{* * *}$ \\
& $(0.000)$ & $(0.000)$ & $(0.000)$ \\
\hline GD & $0.4235^{* * *}$ & 0.1529 *** & $0.0787^{* *}$ \\
& $(0.000)$ & $(0.000)$ & $(0.015)$ \\
\hline SHA & $0.0628^{* * *}$ & $0.2848^{* * *}$ & $0.2272^{* * *}$ \\
& $(0.000)$ & $(0.000)$ & $(0.001)$ \\
\hline COS & -0.0003 & $-0.0010^{* *}$ & 0.0006 \\
& $(0.556)$ & $(0.040)$ & $(0.406)$ \\
\hline BIND & $0.0011^{*}$ & $0.0018^{* * *}$ & $0.0033^{* * *}$ \\
& $(0.088)$ & $(0.007)$ & $(0.004)$ \\
\hline ACI & $0.0088^{* * *}$ & $0.0083^{* * *}$ & $0.0087 * * *$ \\
& $(0.000)$ & $(0.000)$ & $(0.000)$ \\
\hline BMF & 0.0008 & -0.0123 & -0.0258 \\
& $(0.978)$ & $(0.681)$ & $(0.386)$ \\
\hline INST & $0.0229^{* * *}$ & $0.0298^{* * *}$ & $0.0188^{*}$ \\
& $(0.007)$ & $(0.000)$ & $(0.087)$ \\
\hline PROF & $0.4805^{* * *}$ & $0.2302^{* * *}$ & $0.1074 *$ \\
& $(0.000)$ & $(0.000)$ & $(0.051)$ \\
\hline LEV & $0.1068^{* * *}$ & $0.1057^{* * *}$ & $0.1370^{* * *}$ \\
& $(0.000)$ & $(0.000)$ & $(0.000)$ \\
\hline GR & $0.0496^{* *}$ & $0.0344^{* *}$ & $0.0696 * * *$ \\
& $(0.0332)$ & $(0.030)$ & $(0.008)$ \\
\hline SIZE & $0.0074^{* *}$ & $0.0235^{* * *}$ & $0.0060^{* *}$ \\
& $(0.024)$ & $(0.000)$ & $(0.014)$ \\
\hline Obs. & 434 & 434 & 434 \\
\hline Instruments & 91 & 94 & 92 \\
\hline Groups & 70 & -3.78 & 70 \\
\hline AR-1 & -3.76 & $(0.013)$ & -3.34 \\
\hline P-Value & $(0.014)$ & -0.15 & $(0.022)$ \\
\hline AR-2 & -0.21 & $(0.651)$ & -0.16 \\
\hline P-Value & $(0.435)$ & 52.54 & $(0.788)$ \\
\hline Hansen test & 50.45 & $(0.756)$ & 50.31 \\
\hline [P-Value] & $(0.743)$ & & $(0.753)$ \\
\hline Hansen test difference & 52.24 & 51.34 \\
\hline & & & \\
\hline
\end{tabular}




\begin{tabular}{|l|l|l|l|}
\hline Variables & Large sample & Medium sample & Small sample \\
\hline$[$ P-Value $]$ & $(0.945)$ & $(0.932)$ & $(0.965)$ \\
\hline F-Significance & $(0.000)$ & $(0.000)$ & $(0.000)$ \\
\hline
\end{tabular}

Note. $* * *, * * *=$ statistical significance at the level of $0.10,0.05$ and 0.01

\section{Conclusion}

This research aims to investigate whether CG mechanisms and FRQ are related with each other in the context of Pakistan. Panel data is used in the current study. STATA software is used to analyses the data as it is suitable for panel data regression. Secondary data is used in this study. Secondary data is acquired from company annual reports, Pakistan Stock Exchange (PSX) website and State Bank of Pakistan website. A sample of 200 firms is extracted over the period 2003-2017. In this study the system GMM is used to examine the relation between CG and FRQ.

The descriptive statistics shows that financial reporting quality of large sample has a mean value of 0.6031 and standard deviation of 0.1387 . However, the mean financial reporting quality of medium and small size firms is 0.5397411 and 0.4847767 respectively. The findings shows that ownership in large sample is dispersed however majority ownership in small sample is held by few shareholders. Furthermore, in large sample institutional ownership is higher however, small sample have lower institutional ownership with a mean value of 28.79835. In small companies the representation of women on board is higher as opposed to large and medium companies. Small firms are mostly family firms therefore women from the family usually sit on the board. The number of meetings held in large sample is higher as contrast with small as well as medium sample. Large size firms have higher board independence as opposed to medium sample and small sample. Large size firms have higher audit committee independence. Furthermore, the representation of minority shareholders on the board of large size firms is also higher. Furthermore, the findings in this study suggest that there is no multicollinearity problem in the data as no correlation exceeds 0.80 .

In order to test instruments validity the study employed the Hansen test. In Hansen test rejection of Ho is required as it indicates that error term is correlated with null hypothesis. Thus, Ho is rejected in this case as the Pvalue is $>0.05$ which suggests that the instruments used are valid instruments. Further, to check whether the problem of autocorrelation is present in the data the study uses Arellano-Bond test which indicates that p-value is $<5 \%$. Hence, there is no autocorrelation in the dataset.

The findings suggest that board independence enhances FRQ by $0.0011 \%$ in large sample, 0.0018 in medium sample and 0.0033 in small sample. Thus, independence of the board and FRQ are positively correlated the findings also indicate that the variable board independence brings higher increase in FRQ in small sample. In addition, audit committee independence raises FRQ in all three samples. At the $1 \%$ level these results are highly significant. Specifically, a rise of $1 \%$ in audit committee independence increases FRQ by $0.0088 \%$ in large sample, $0.0083 \%$ in medium sample and 0.0087 in small sample. More often than not managers are involved in earning management so as to cover their astute conduct. The audit committee play an effective role in improving financial statements quality and hence FRQ by monitoring the work of internal auditors. The results show that institutional ownership improves the FRQ of Pakistani firms. More specifically, the result indicates that a $1 \%$ rise in institutional ownership bring $0.022 \%$ increase in large sample, $0.029 \%$ in medium sample and $0.018 \%$ in small sample. The presence of institutional investors protects minority shareholders' interests and performs a significant monitoring role on the board.

The variable gender diversity has significant positive relationship with FRQ in small, medium and large sample. The coefficient show that a rise of $1 \%$ in gender diversity brings about $42 \%$ increase in large sample, $15 \%$ in medium sample and 7\% increase in small sample. Shareholder activism is other explanatory variable where the coefficient FRQ is significant and positive in all three samples of small, medium and large samples. The result indicates that a $1 \%$ rise in shareholder activism is associated with an increase of $6 \%$ (large sample), $28 \%$ (medium sample) and $22 \%$ (small sample) respectively. Concentrate ownership insignificantly affect FRQ in case of large and small sample but on other hand in medium size firm's the relationship is significant and positive with FRQ. A $1 \%$ increases in concentrated ownership is associated with a decrease of 0.001 in FRQ in the case of medium size firms. The variables monitory shareholder representation and board meeting frequency does not affect FRQ. Furthermore, the control variables leverage, growth, firm size, and profitability have positive and significant association with FRQ in all three samples.

\section{References}

Al-Shetwi, M., Ramadili, S.M., Chowdury, T.H.S., \& Sori, Z.M. (2011). Impact of internal audit function on financial reporting quality: Evidence from Saudi Arabia. African Journal of Business Management, Vol, 5 , 11189-11198.

Al-Shaer, H., Salama, A., \& Toms, S. (2017). Audit committees and financial reporting quality: evidence from 
UK environmental accounting disclosures. Journal of Applied Accounting Research, Vol, 18, 2-21.

Ansah, S.O. (2000). Timeliness of corporate financial reporting in emerging capital markets: empirical evidence from the Zimbabwe Stock Exchange. Accounting and Business Research, Vol, 12, 241-254.

Asegdew, K. (2016). Determinants of financial reporting quality: evidence from large manufacturing share companies of Addis Ababa. Submitted to Addis Ababa University.

Armstrong, C.S., Guay, W.R., \& Weber, J.P. (2010). The Role of Information and Financial Reporting in Corporate Governance and Debt Contracting. Journal of Accounting and Economics, Vol, 15, 179-234.

Bajra, U., \& Cadez, S. (2016). The impact of corporate governance quality on earnings management: evidence from European companies cross-listed in the US. Australian Accounting Review, Vol, 4, 1-15.

Baek, J.S., Kang, J.K., \& Park, K.S. (2004). Corporate governance and firm value: Evidence from the Korean financial crisis. Journal of Financial Economics, Vol, 7, 265-313.

Bajra, U., \& Cadez, S. (2018). The impact of corporate governance quality on earnings management: evidence from European companies cross-listed in the US. Australian Accounting Review, Vol, 28, 152-166.

Biddle, G.C., Hilary, G., \& Verd, R.S. (2009). How does financial reporting quality relate to investment efficiency? Journal of Accounting and Economics, Vol, 5, 112-131.

Bushman, R.M. (2014). Thoughts on financial accounting and the banking industry. Journal of Accounting and Economics, Vol, 58, 384-395.

Chen, F., Hope, O.K., Li, Q., \& Wang, X. (2011). Financial reporting quality and investment efficiency of private firms in emerging markets. The Accounting Review, Vol, 86, 1255-1288.

Claessens, S., \& Fan, J.P. (2002). Corporate governance in Asia: A survey. International Review of Finance, Vol, $15,71-103$.

Cohen, J., Krishnamoorthy, G., \& Wright, A. (2004). The corporate governance mosaic and financial reporting quality. Journal of Accounting Literature, Vol, 24, 87-152.

Cornett, M.M., Marcus, A.J., \& Tehranian, H. (2008). Corporate governance and pay-for-performance: The impact of earnings management. Journal of Financial Economics, Vol, 31, 357-373.

Costello, A., \& Moerman, R.W. (2010). The impact of financial reporting quality on debt contracting: Evidence from internal control weakness reports. Journal of Financial Economics, Vol, 18, 1-52.

Denis, K.D., \& McConnell J.J. (2001). International Corporate Governance. Journal of Financial and Quantitative Analysis, Vol, 15, 1-58.

Durnev, A., Li, T., \& Magnan, M. (2011). Beyond tax avoidance: Offshore firms' institutional environment and financial reporting. Journal of Law and Management, Vol, 16, 1-58.

Ezat A., \& El-Masry, A. (2008). The impact of corporate governance on the timeliness of corporate internet reporting by Egyptian listed companies. Managerial Finance, Vol, 34, 848-867.

Góis, C.G. (n.d.). Financial Reporting Quality and Corporate Governance: The Portuguese Companies Evidence.

Hay, D., Stewart, J., \& Redmayne, N.B. (2017). The role of auditing in corporate governance in Australia and New Zealand: A research synthesis. Australian Accounting Review, Vol, 19, 457-479.

Hirshleifer, D., \& Teoh, S.H. (2003). Limited attention, information disclosure, and financial reporting. Journal of Accounting and Economics, Vol, 26, 337-386.

Husnin, Ihsan, A., Nawawi, A., \& Saiful, A. (2016). Corporate governance and auditor quality-Malaysian evidence. Asian Review of Accounting, Vol, 24, 202-230.

Ibadin, I.M., Izedonmi, F., \& Ibadin, P.O. (2012). The association between selected corporate governance attributes, company attributes and timeliness of financial reporting in Nigeria. Journal of Finance and Accounting, Vol, 17, 137-144.

Jenny, K., \& Redmayne, N. (2017). The Role of Auditing in Corporate Governance in Australia and New Zealand: A Research Synthesis. Australian Accounting Review, Vol, 23, 457-479.

Kent, P., \& Stewart, J. (2008). Corporate governance and disclosures on the transition to international financial reporting standards. Bond Business School Publications, Vol, 15, 1-40.

Khan, M.H.U.Z. (2011). The effect of corporate governance elements on corporate social responsibility (CSR) reporting Empirical evidence from private commercial banks of Bangladesh. Journal of Law and Management, Vol, 21, 82-108.

Klai, N., \& Omri, A. (2011). Corporate governance and financial reporting quality: The case of tunisian firms. International Business Research, Vol, 23, 158-166.

Klai, N., \& Omri, A. (2011). Corporate Governance And Financial Reporting Quality: The case of Tunisian firms. International Business Research, Vol, 4, 158-166.

Kelton, A., \& Yang, Y.W. (2004). The Impact of corporate governance on internet financial reporting. International Accounting Policy Forum, Vol, 14, 1-28.

Khan, M.H.U.Z. (2011). The effect of corporate governance elements on corporate social responsibility (CSR) reporting Empirical evidence from private commercial banks of Bangladesh. Journal of Law and Management, Vol, 22, 82-108. 
Krishnan, J., Wen, Y., \& Zhao, W. (2011). Legal expertise on corporate audit committees and financial reporting quality. The Accounting Review, Vol, 86, 2099-2130.

Krishnan, J., Wen, Y., \& Zhao, W. (2011). Legal expertise on corporate audit committees and financial reporting quality. The Accounting Review, Vol, 15, 2099-2130.

Lin, J.W., \& Hwang, M.I. (2010). Audit quality, corporate governance, and earnings management: A metaanalysis. International Journal of Auditing, Vol, 8, 57-77.

Mayangsari S., Murwaningsari, E., \& Lastanti, H.S. (2018). The role of financial reporting quality and corporate governance on competition: Evidence from mining companies. Media Riset Akuntansi, Auditing and Information, Vol, 18, 187-204.

McGee, R.W., \& Yuan, X. (2008, may). Corporate governance and the timeliness of financial reporting: An empirical study of the people's republic of china. Florida International University (Working Paper).

Ojah, K., Mokoaleli, T., \& Mokoteli, T. (2012). Internet financial reporting, infrastructures and corporate governance: An international analysis. Review of Development Finance, Vol, 26, 69-83.

Penman, S.H. (2007). Financial reporting quality: Fair value. International Accounting Policy Forum, Vol, 14, $33-$ 44.

Piotroski, J.D., \& Wong, T.J. (2012). Institutions and information environment of Chinese listed firms. In Capitalizing China (Pp. 201-242). University of Chicago Press.

Pomeroy, B., \& Thornton, D.B. (2008). Meta-Analysis and the accounting literature: The case of audit committee independence and financial reporting quality. European Accounting Review, Vol, 17, 1-39.

Rajgopal, S., \& Venkatachalam, M. (2010). Financial reporting quality and idiosyncratic return volatility. Journal of Applied Accounting, Vol, 25, 1-60.

Shaer, H.A., Salama, A., \& Toms, S. (2017). Audit committees and financial reporting quality Evidence from UK environmental accounting disclosures. Journal of Applied Accounting, Vol, 7, 2-21.

Shetwi, M.A., Ramadili, S.M., Chowdury, T.H., \& Sori, Z.M. (2011). Impact of internal audit function (IAF) on financial reporting quality (FRQ): Evidence from Saudi Arabia. African Journal of Business Management, Vol, 4, 11189-11198.

Yetman, M.H., \& Yetman, R.J. (2004). The effects of governance on the financial reporting quality of nonprofit organizations. Journal of Applied Accounting, Vol, 5, 1-49.

Zia, A. (2017). Impact of corporate governance on financial reporting quality: Evidence from Pakistan. Journal of Finance and Accounting, Vol, 4, 1-63. 